\title{
TERMINY W POSTĘPOWANIU CYWILNYM - ZAGADNIENIA WYBRANE
}

\section{Uwagi wprowadzające}

Terminowość (czas) dokonywania czynności, jak się wydaje, nabiera szczególnego znaczenia w ramach formalnych procedur przed sądem orzekającym. Oprócz usprawnienia samego biegu postępowania ma też za zadanie realizację jednej z zasad cywilnego postępowania sądowego, a mianowicie jego szybkości, co wynika $\mathrm{z}$ art. 6 kpc. ${ }^{1}$ Wszystkie systemy postępowania, nie wyłączając kodeksu postępowania cywilnego, oparte są na zasadzie prekluzyjności wyrażającej się w tym, że czynności stron i sądu muszą być dokonywane w określonych przez prawo terminach. ${ }^{2}$ Żeby osiagnąć ów cel, ustawodawca przewidział różnego rodzaju terminy, tak dla stron, uczestników postępowania, jak i sądu, i obwarował stosowną sankcją uchybienia w zakresie ich niedochowania. Ustawowe sankcje związane z niedokonaniem w terminie czynności procesowej mają jedynie na celu zapobiegać wszelkiej spekulacji (np. działaniu na zwłokę) i opieszałości w procesie, czyli przeciwdziałać zawinionemu przewlekaniu procesu. ${ }^{3}$

Na pierwszy rzut oka mogłoby się wydawać, iż problematyka związana z terminami w postępowaniu cywilnym jest prosta i nieskomplikowana. Rzeczywiście pojęcie „termin” samo w sobie jest raczej przejrzyste. Natomiast ta sama problematyka nabiera szczególnego znaczenia, jeżeli ów „termin” połączymy z instytucjami, w odniesieniu do których ustawodawca uznał za zasadne stwierdzić, że powinny być dokonane w określonym terminie. I właśnie przez pryzmat skutków dokonania, tudzież niedokonania tych czynności procesowych najczęściej tworzona jest analiza czasowości i terminowości w postępowaniu cywilnym. To wszystko powoduje,

\footnotetext{
Ustawa z dnia 17 listopada 1964 r. Kodeks postępowania cywilnego, Dz.U. Nr 43, poz. 296 z późn. zm.

F. Rosengarten, Przywrócenie terminu, a prawomocność orzeczeń cywilnych, „Palestra” 1974, nr 3, s. 46.

K. Piasecki, Uchybienie i przywrócenie terminu czynności procesowej strony w sprawach cywilnych, „Palestra” 1961 , nr 5, s. 10.
} 
iż przedmiotowa problematyka jest złożona i skomplikowana, dlatego też ze względu na raczej ogólne zagadnienia czasu w procedurze będące przedmiotem niniejszego opracowania postanowiłem rozważania ograniczyć do zagadnień poświęconych rodzajom terminów w kpc. oraz w pewnym zakresie odnieść się do możliwej przewlekłości postępowania sądowego $\mathrm{z}$ uwagi m.in. na uchybienia $\mathrm{w}$ zakresie terminowości czynności podjętych przez sąd, które skutkować mogą stwierdzeniem przewlekłości postępowania $\mathrm{w}$ sprawie (w tym przypadku widać bowiem wyraźnie zależność między terminami na dokonywanie czynności a możliwością przypisania odpowiedzialności organowi procesowemu).

Rozważania, ze względów metodologicznych, należy rozpocząć od słownikowego wyjaśnienia samego pojęcia „termin”. Zgodnie z jego objaśnieniem, w ujęciu nas interesującym, w Słowniku Języka Polskiego pod red. M. Szymczaka oznacza on - czas, w którym jakaś czynność powinna być wykonana, czas wyznaczony na wykonanie jakiejś czynności, na dopełnienie jakiś warunków. ${ }^{4}$ Kodeks postępowania cywilnego w swojej treści posiada dwa rozdziały poświęcone wprost terminom: po pierwsze, rozdział „Terminy” (art. 164-166 kpc.); po drugie, rozdział „Uchybienie i przywrócenie terminu" (art. 167-172 kpc.). Dodać jednak należy, iż kodeks zawiera także inne przepisy, w których jest mowa o terminach, wyrażonych za pomocą różnych określeń, a które można podzielić na dwie grupy. Do pierwszej z nich zaliczymy takie zwroty, jak: termin, ciagg, okres, czas, data chwila, jednostka miary czasu, do drugiej - określony moment postępowania (zagadnienie to jest jednak dyskusyjne - stwierdzenie własne A.B. $\left.{ }^{5}\right) .{ }^{6}$ Problematyczna i trudna zarazem staje się próba odpowiedzi na pytanie, czy wszystkie określenia, które w jakiś sposób wiążą się z czasem, mogą być potraktowane jako „termin” w znaczeniu procesowym? Stwierdzić generalnie należy, iż terminy procesowe określane są za pomocą takich jednostek czasu, jak dzień, tydzień, miesiąc, rok. Przyjmuje się, że nie mogą być traktowane jako terminy okresy czasu oznaczone nie w tego rodzaju jednostkach, ale w inny sposób, w szczególności przez wskazanie określonych zdarzeń procesowych, czy też przy pomocy słów „,czas”, „data”, „,chwila”. ${ }^{7}$ Nie jest także termi-

5 Polemika w tym zakresie wywiązała się przede wszystkim pomiędzy W. Siedleckim a W. Broniewiczem. Według pierwszego z nich okresy te są terminami określonymi w inny sposób, niż w jednostkach miary czasu, ale przez odniesienie ich do innych czynności procesowych lub pewnych stadiów postępowania (W. Siedlecki, Kodeks postępowania cywilnego. Komentarz, t. I, Warszawa 1969, s. 277). Drugi natomiast stoi na stanowisku, iż gdyby przyjać, iż okresy te są terminami, to nie można by było stosować do nich przepisów kpc., a w szczególności przepisów o przywróceniu uchybionego terminu (W. Broniewicz, Terminy w postępowaniu cywilnym, NP 1971 nr 9, s. 1322.). - zob. także - M. Sorysz, Terminy w polskim procesie cywilnym, Warszawa 2007, s. 17.

Ibidem, s. 10. Autor przykładowo do pierwszej grupy zalicza następujące: art. $130 \S 1 \mathrm{kpc}$. - termin dla strony do poprawienia lub uzupełnienia pisma zawierającego braki formalne; art. $251 \S 1 \mathrm{kpc}$. - strona może w ciagu dwóch tygodni od ogłoszenia wyroku żądać jego uzupełnienia; art. 206 kpc. - termin rozprawy wyznacza przewodniczący (dzień rozprawy); art. 867 § 3 kpc. - o terminie i miejscu licytacji komornik zawiadomi dłużnika (dzień licytacji); art. 492 § $1 \mathrm{kpc}$ - nakaz od chwili wydania stanowi tytuł zabezpieczenia (od dnia wydania). Do drugiej natomiast przykładowo: art. $203 \S 1 \mathrm{kpc}$. - cofnięcie pozwu może nastapić aż do rozpoczęcia rozprawy lub aż do wydania wyroku. - Ibidem, s. 10-17. 
nem procesowym określenie wskazujące datę (dzień i godzinę), w której ma nastąpić podjęcie określonej czynności, np. przeprowadzenie dowodu (art. 236 kpc.). ${ }^{8}$ Wszystko to powoduje, iż skomplikowanym staje się próba stworzenia uniwersalnej definicji „termin procesowy". ${ }^{9}$ Jedną z takich definicji proponuje M. Sorysz. Według tego autora terminem procesowym jest wyznaczony przez ustawę lub organ procesowy odcinek czasu, w obrębie którego podmiot postępowania może skutecznie podjąć oznaczoną czynność procesowa, jak też odcinek czasu określony przez podmioty postępowania, w obrębie którego nie moga być skutecznie podejmowane czynności procesowe za wyjątkiem tych czynności, które mają na celu podjęcie postępowania, zabezpieczenie powództwa lub dowodu. ${ }^{10}$

Zgodnie z brzmieniem art. $165 \S 1 \mathrm{kpc}$. terminy oblicza się według przepisów prawa cywilnego. To krótkie sformułowanie niesie ze sobą poważne konsekwencje prawne. Nie ma bowiem żadnych różnic między sposobem obliczania terminów procesowych zarówno sądowych, jak ustawowych, czy też terminu umownego a obliczaniem terminów materialnoprawnych. Takie rozwiązanie jest słuszne, bowiem w ramach tego samego systemu prawnego nie powinno być różnic w regulacji takich samych instytucji prawnych. Rozwiązanie to stanowi wyraz jednolitości prawa cywilnego (materialnego i formalnego). ${ }^{11}$ Niemniej jednak stosowanie przepisów kc. do obliczania terminów procesowych musi uwzględniać ich specyfikę, dlatego w istocie można mówić o stosowaniu art. 111, 112 i 115 kc. i ograniczonym stosowaniu art. $113 \mathrm{i} 116 \mathrm{kc} .^{12}$ Tematyka terminów stała się przedmiotem rozważań Sądu Najwyższego w postanowieniu z dnia 14 czerwca 2005 r. z którego wynika, że: ,artykuł 112 kc., do którego odsyła art. $165 \S 1$ kpc., ma zastosowanie tylko przy terminach ciąłych, a taki charakter mają terminy procesowe. Do ich obliczania nie można stosować art. 114 kc., który określa sposób obliczania terminu oznaczonego w miesiącach i latach, gdy ciagłość terminu nie jest wymagana."13 Warto jeszcze zaznaczyć, że w momencie wejścia w życie kpc. wyróżniał on tylko terminy, których długość była wyrażona w tygodniach, miesiącach i latach. Ustawodawca, dokonując wielokrotnych nowelizacji ustawy po 1989 r. w sposób przypadkowy wprowadził do niego terminy oznaczone w dniach (np. art. $767 \S 4$ kpc.), gdzie ten sam termin można byłoby oznaczyć, przyjmując dotychczasowy podział terminów występujących na gruncie ustawy. ${ }^{14}$

\footnotetext{
$8 \quad$ M. Jędrzejewska, K. Weitz, (w:) T. Ereciński (red.), Kodeks postępowania cywilnego. Komentarz, cz. I, t. I, wyd. 3, Warszawa 2009, s. 460.

Przegląd stanowisk w tej materii przedstawia M. Sorysz, Terminy w polskim procesie cywilnym, s. 19-20. Ibidem, s. 20.

A. Zieliński, (w:) A. Zieliński, K. Flaga-Gieruszynska, Kodeks postępowania cywilnego. Komentarz, wyd. 4, Warszawa 2010, s. 306.

M. Jędrzejewska, K. Weitz, (w:) T. Ereciński (red.), Kodeks postępowania cywilnego. Komentarz, s. 462. Postanowienie SN z 14 czerwca 2005r., V CZ 63/05, Lex nr 512034.

Tak M. Sorysz, Terminy w polskim procesie cywilnym, s. 46.
} 


\section{Rodzaje terminów procesowych i ich klasyfikacje}

Dopiero zatem teraz, po tych niejako wstępnych wywodach, można przejść do problematyki rodzajów terminów w kpc. Kryteriów ich podziałów można wskazać wiele $^{15}$, natomiast skupić chciałbym się na podziale najbardziej klasycznym wyróżnianym tak przez Kodeks, jak i doktrynę procesu cywilnego. Wyróżnia się terminy ustawowe, sądowe, umowne i instrukcyjne. ${ }^{16}$ Kryterium tego podziału stanowi źródło powstania danego terminu. Można stwierdzić, że z podziałem tym wiąże się też kwestia, do kogo adresowany jest dany termin. Ustawa procesowa w jednoznaczny sposób odróżnia czynności, które może podjąć organ procesowy, od czynności, których może dokonać uczestnik postępowania w określonym terminie. ${ }^{17}$

Termin ustawowy - cechą charakterystyczną tego terminu jest to, że nie może on być skrócony ani przedłużony na mocy decyzji organu procesowego albo egzekucyjnego, czy też na mocy porozumienia uczestników postępowania. ${ }^{18}$ Są to terminy przewidziane w ustawie (np. terminy do wniesienia środków zaskarżenia). Można wśród nich wyróżnić terminy ad quem, przed których upływem czynność powinna być dokonana (np. dwutygodniowy termin do wniesienia apelacji, art. 369 $\S 1 \mathrm{kpc}$.) oraz terminy post quem, po których upływie czynność może być dokonana (np. roczny albo pięcioletni termin z art. $182 \S 1 \mathrm{kpc}$., po których upływie sąd powinien umorzyć zawieszone postępowanie) ${ }^{19}$ Ustawa stanowi źródło terminu ustawowego, jak i instrukcyjnego, jest źródłem powstania terminu oraz dopuszczalności czynności, dla której jest on przewidziany. ${ }^{20}$

Termin sądowy - terminem sądowym jest w myśl art. 164 kpc. termin wyznaczony przez sąd (referendarza sądowego) albo przez przewodniczącego. Terminem sądowym jest też termin wyznaczony przez sędziego wyznaczonego (art. $239 \mathrm{kpc}$.), a także komornika. Ponieważ przewodniczący, sąd, sędzia wyznaczony i komornik tworzą grupę podmiotów postępowania, którą można określić jako organy procesowe i egzekucyjne, należy przyjąć, że terminem sądowym jest termin wyznaczony przez organ procesowy albo egzekucyjny. ${ }^{21}$ Terminy sądowe, w przeciwieństwie do terminów ustawowych, mogą, ale nie muszą występować w danym toczącym się postępowaniu. ${ }^{22}$ Głównym celem tych terminów jest zapewnienie prawidłowego toku postępowania oraz zapobieżenie przewlekłości postępowania. Można zatem

Patrz przykładowo M. Sorysz, ibidem, s. 20-28.

Patrz przykładowo Z. Resich, (w:) J. Jodłowski, Z. Resich, J. Lapierre, T. Misiuk-Jodłowska, K. Weitz, Postępowanie cywilne, wyd. 6, Warszawa 2009, s. 296; B. Bladowski, Metodyka pracy sędziego cywilisty, wyd. 3, Warszawa 2009, s. 94-95.

M. Sorysz, Terminy w polskim procesie cywilnym, s. 21.

W. Broniewicz, Terminy w postępowaniu cywilnym, s. 1322-1323.

Z. Resich, (w:) J. Jodłowski, Z. Resich, J. Lapierre, T. Misiuk-Jodłowska, K. Weitz, Postępowanie cywilne, s. 296.

M. Sorysz, Terminy w polskim procesie cywilnym, s. 21.

Tak W. Broniewicz, Terminy w postępowaniu cywilnym, s. 1323.

Tak M. Sorysz, Terminy w polskim procesie cywilnym, s. 21-22. 
pokusić się o stwierdzenie, że terminami sądowymi nazywamy odcinki czasowe wyznaczone przez organ procesowy w zakresie jego uprawnień, w obrębie których uczestnik postępowania może podjąć oznaczoną czynność procesową, która będzie warunkować powstanie lub też nie określonych skutków procesowych. ${ }^{23}$

Terminy instrukcyjne - są to terminy przewidziane dla czynności sądu, mające zapewnić sprawność działania organów sądowych w postępowaniu cywilnym. Ich uchybienie nie daje stronom uprawnień do kwestionowania czynności sądu. Terminem takim jest przykładowo termin dla ogłoszenia wyroku z art. $326 \S 1$ kpc., dający sądowi możliwość jednokrotnego odroczenia jego ogłoszenia na czas do dwóch tygodni. ${ }^{24}$ Są one szczególnym rodzajem terminów ustawowych skierowanych tylko do organu procesowego. O tym, że są to terminy ustawowe, przesądza fakt, że źródłem ich powstania jest ustawa, która określa również ich długość. Oznacza to, że uczestnicy postępowania i organ procesowy nie mają żadnego wpływu na ich powstanie i długość terminu, który nie może być skrócony ani przedłużony przez ich jakiekolwiek czynności. ${ }^{25}$

Termin umowny - jest to termin wyznaczony w umowie przez uczestników postępowania. Kpc. przewiduje taki termin tylko w jednym wypadku - w razie zawieszenia postępowania na zgodny wniosek uczestników postępowania (art. $178 \mathrm{kpc}$. i art. 181 pkt 2 kpc.). Jednocześnie uczestnicy mogą oznaczyć termin owego zawieszania nie krótszy niż trzy miesiące (ustawowo określona dolna granica), licząc od daty postanowienia o zawieszeniu i nie dłuższy niż rok czasu od tego postanowienia $^{26}$ (taki wniosek wynika z treści art. $182 \S 1 \mathrm{kpc}$.). ${ }^{27}$ Termin umowny, podobnie jak termin ustawowy i sądowy, jest odcinkiem czasowym, w obrębie którego - odmiennie niż jest to przy terminach ustawowych i sądowych - strona nie może podjąć skutecznie żadnych czynności procesowych za wyjątkiem czynności, które mają na celu podjęcie zawieszonego postępowania, zabezpieczenie powództwa lub dowodu. Wprowadzenie tego terminu było podyktowane dążeniem do zapewnienia uczestnikom postępowania realizacji przysługującej im zasady rozporządzalności - prawami lub roszczeniami (rozporządzalności materialnej) i czynnościami procesowymi, biegiem postępowania (rozporządzalność formalna). ${ }^{28}$

Powyższe rodzaje terminów należą do kanonu nauki procesu cywilnego. Jednocześnie trzeba mieć na względzie, iż kpc. ciągle ewoluuje, wprowadzając rozwiąza-

23 Ibidem, s. 33.

24 Z. Resich, (w:) J. Jodłowski, Z. Resich, J. Lapierre, T. Misiuk-Jodłowska, K. Weitz, Postępowanie cywilne, s. 297.

25 M. Sorysz, Terminy w polskim procesie cywilnym, s. 36.

26 Warto w tym miejscu odnieść się do orzeczenia Sądu Najwyższego z dnia 25 października 1974 r., III PRN 45/74, OSNC $1975 \mathrm{nr} 4$, poz. 70, który stwierdził, iż początkowym terminem okresu, po upływie którego sąd umarza postępowanie, jest, zgodnie z art. $182 \S 1$ kpc., data postanowienia o zawieszeniu postępowania, a nie dzień uprawomocnienia się tego postanowienia.

27 W. Broniewicz, Terminy w postępowaniu cywilnym, s. 1323.

28 M. Sorysz, Terminy w polskim procesie cywilnym, s. 35-36. 
nia, które co jakiś czas mogą skutkować modyfikacją nawet klasycznych pojęć tudzież podziałów. Przykładem takiej zmiany jest wprowadzenie do kpc. art. $130 \S 11$ w brzmieniu: jeżeli pismo wniosła osoba zamieszkała lub mająca siedzibę za granicą, która nie ma w kraju przedstawiciela, przewodniczący wyznacza termin do poprawienia lub uzupełnienia pisma albo uiszczenia opłaty nie krótszy niż miesiąc. Przepis ten jest rozwinięciem regulacji zawartej w art. $130 \S 1 \mathrm{kpc}$., regulującego zasady usuwania braków formalnych i fiskalnych pisma procesowego (jest to niewątpliwie termin ustawowy, ponieważ źródłem jego powstania jest ustawa, która określa jego długość). Natomiast terminowi z art. $130 § 11 \mathrm{kpc}$. można, jak się wydaje, przypisać inny, podwójny charakter. $Z$ jednej strony można przyjąć, że jest to termin sądowy, skoro termin ten zostaje wyznaczony przez przewodniczącego, który musi oznaczyć jego długość. Ustawodawca jednak w zakresie długości terminu postawił warunek, iż nie może on być krótszy niż miesiąc. Oznaczać to może, że w tym zakresie jest to termin ustawowy, skoro to ustawa określa jego minimalną długość. ${ }^{29} \mathrm{Na}$ możliwość takiej interpretacji wskazanego przepisu (aczkolwiek nie wprost) zdają się także wskazywać M. Jędrzejewska i K. Weitz stwierdzając, iż termin miesięczny - w przeciwieństwie do terminu tygodniowego $-\mathrm{z}$ art. $130 \S 1 \mathrm{kpc}$. jest terminem sądowym o charakterze minimalnym (art. 164 kpc.), może być więc na wniosek strony przedłużony (art. $166 \mathrm{kpc}$.). ${ }^{30}$

Z powyższego, z konieczności ogólnego podziału wynika niezbicie, iż tzw. terminy procesowe bardzo różnią się od siebie. Nie są one jednolite, co podyktowane jest funkcjami (jakie pełnia), celami, jakie mają do zrealizowania. Dlatego też należy odnieść się do podstawowych cech odróżniających je od siebie, zestawiając je ze sobą, a także je upodabniających.

Odnosząc się do klasycznego podziału terminów w kpc. na ustawowe, sądowe, umowne, instrukcyjne i termin ustawowo-sądowy, można dojść do wniosku (stosując także dodatkowe kryteria ocenne), że wśród terminów ustawowych występują terminy przywracane na podstawie (art. $168 \mathrm{kpc}$.) i nieprzywracane z uwagi na występujący w tym względzie zakaz ustawowy. Zarówno jedne, jak i drugie są kierowane do podmiotów postępowania dla podjęcia przez nie określonych czynności, są one maksymalne, bez możliwości ich przedłużenia, a uchybienie tych terminów pociąga za sobą bezskuteczność dokonanej przez te podmioty czynności procesowej. Szczególnym rodzajem terminów ustawowych jest termin instrukcyjny, nieprzywracany, który jest skierowany tylko i wyłącznie do organu procesowego. Podobnie jak terminy ustawowe skierowane do stron postępowania jest on maksymalny, z tym że bez sankcji bezskuteczności czynności dokonanej po jego upływie. ${ }^{31}$

29 M. Sorysz, Terminy w polskim procesie cywilnym, s. 39.

30 M. Jędrzejewska, K. Weitz, (w:) T. Ereciński (red.), Kodeks postępowania cywilnego. Komentarz, s. 415.

31 M. Sorysz, op. cit., s. 40-41. 
Długość terminów sądowych zależy od uznania sądu lub przewodniczącego i dyktowana jest okolicznościami, jakie zachodzą w konkretnej sprawie. W nielicznych wypadkach ustawa wskazuje granice, w jakich musi mieścić się wyznaczany termin (termin wyznaczany w ogłoszeniu o wszczęcie postępowania o uznanie za zmarłego musi zawrzeć się w granicach od trzech do sześciu miesięcy - art. $530 \S 1$ pkt 2 kpc., lub maksymalną jego długość (termin do wszczęcia postępowania w przypadku tymczasowego zabezpieczenia roszczenia nie może przekraczać dwóch tygodni - art. $733 \mathrm{kpc}$., lub minimalny czas trwania (termin do uzupełnienia braku pisma w postaci jego nieopłacenia osobie zamieszkałej za granicą nie może być krótszy niż miesiąc (art. $130 \S 11 \mathrm{kpc}$.)). ${ }^{32}$ Zgodnie z brzmieniem art. $166 \mathrm{kpc}$. przewodniczący może z ważnej przyczyny przedłużyć lub skrócić termin sądowy na wniosek zgłoszony przed upływem terminu, nawet bez wysłuchania strony przeciwnej. Przedłużenia albo skrócenia terminu sądowego wyznaczonego przez sąd albo przewodniczącego dokonuje zawsze ten ostatni ${ }^{33}$ mocą zarządzenia. W stosunku do terminów ustawowych terminy sądowe różnią się odnośnie do skutków procesowych w przypadku zawieszenia postępowania rozpoznawczego na zgodny wniosek uczestników postępowania, wskutek niestawiennictwa stron lub niemożności nadania sprawie dalszego biegu. Zgodnie bowiem $\mathrm{z}$ art. $179 \S 1 \mathrm{kpc}$. zawieszenie postępowania z tych przyczyn wstrzymuje tylko bieg terminów sądowych, które biegną dalej dopiero z chwilą podjęcia postępowania, nie wstrzymuje natomiast biegu terminów ustawowych. ${ }^{34}$ Terminy ustawowe i sądowe są terminami prekluzyjnymi, a zatem ich uchybienie powoduje, że czynność procesowa podjęta przez stronę po ich upływie jest bezskuteczna (art. $167 \mathrm{kpc}$.). Skutek ten następuje ipso iure, chyba że przepis szczególny stanowi inaczej (do niedawna przykładem tego typu zachowania sądu mógł być art. $1124 \S 3 \mathrm{kpc}$. uzależniający możliwość odrzucenia pozwu lub środka odwoławczego na skutek braku kaucji aktorycznej od wniosku pozwanego - od 1 lipca 2009 r. ten mechanizm nie ma już zastosowania). Sąd nie powinien uwzględniać czynności procesowej dokonanej po upływie terminu dla niej wyznaczonego, jednak w wielu wypadkach przyjąć trzeba (zależnie zwłaszcza od rodzaju czynności procesowej), że zachowuje ona swoją skuteczność, np. nie podlega odrzuceniu odpowiedź na apelację wniesiona po upływie ustawowego dwutygodniowego terminu określonego w art. $372 \mathrm{kpc} .{ }^{35}$ Bieg terminu sądowego wyzna-

32 M. Jędrzejewska, K. Weitz, (w:) T. Ereciński (red.), Kodeks postępowania cywilnego. Komentarz, s. 461.

33 Dopuszcza się także możliwość wydania postanowienia w tej materii przez sąd - patrz M. Jędrzejewska, K. Weitz (w:) T. Ereciński (red.), Kodeks postępowania cywilnego. Komentarz, s. 465.

34 Patrz także W. Broniewicz, Terminy w postępowaniu cywilnym, s. 1323.

35 B. Bladowski, Metodyka pracy sędziego cywilisty, s. 96. Takie stanowisko zdaje się potwierdzać także W. Broniewicz, jednocześnie wskazując, iż bezskuteczna będzie w razie podjęcia po upływie terminu sądowego taka czynność, jak przykładowo uzupełnienie braków sprzeciwu od wyroku zaocznego, rewizji (obecnie apelacji), zażalenia, jeżeli w chwili dokonania tej czynności minął już termin wniesienia danego środka zaskarżenia. Na podstawie bowiem analogii $z$ art. $130 \S 3 \mathrm{kpc}$. każdy z wymienionych środków zaskarżenia w razie uzupełnienia jego braków w wyznaczonym terminie wywoła skutki od chwili jego wniesienia. A contrario w razie uzupełnienia tych braków po upływie wyznaczonego w tym celu terminu dany środek zaskarżenia nie wywoła skutków od chwili wniesienia - W. Broniewicz, Terminy w postępowaniu cywilnym, s. 1324. 
czonego przez sąd lub przewodniczącego rozpoczyna się z chwilą ogłoszenia w tym przedmiocie postanowienia lub zarządzenia (dotyczy to rozpraw lub innych posiedzeń jawnych), a gdy Kodeks przewiduje doręczenie z urzędu - od jego doręczenia (w odniesieniu do posiedzeń niejawnych) (art. $164 \mathrm{kpc}$.). Przepis ten wskazuje jedynie początek biegu terminu sądowego w sposób odmienny niż początek biegu terminów ustawowych. Natomiast sposób obliczania terminów jest dla wszystkich rodzajów terminów procesowych jednakowy i wynika $\mathrm{z}$ art. $165 \mathrm{kpc} .{ }^{36}$

Ciekawą, aczkolwiek nie popartą żadną szerszą argumentacją tezę, postawił w jednym ze swoich orzeczeń Sąd Najwyższy, stwierdzając, że zarówno terminy ustawowe, jak i terminy sądowe dla dokonania czynności procesowych mają tę wspólną cechę, że nie mogą rozpocząć biegu w razie, gdy sąd nie wskaże stronie ich długości. ${ }^{37}$ Wydaje się, że może chodzić tutaj przykładowo o sytuację, w której organ procesowy w związku z dokonaną czynnością jest zobowiązany podjać inną dodatkową czynność, która wpływa na przewidziany przez ustawę termin (np. art. 327 kpc., 357 § 1 kpc. w zw. z art. 327 kpc. przewiduja, że w związku z ogłoszeniem wyroku sąd musi dodatkowo pouczyć o sposobie i terminie zaskarżenia orzeczenia). ${ }^{38}$ Według E. Wengerka brak pouczenia nie ma wpływu na bieg terminu do zaskarżenia orzeczenia, ale może uzasadniać wniosek o przywrócenie uchybionego terminu do złożenia środka zaskarżenia. ${ }^{39}$ Pogląd ten początkowo akceptował także B. Bladowski ${ }^{40}$, później jednak stanął na stanowisku, iż brak pouczenia w sytuacji, gdy taki obowiązek ciążył na organie procesowym, skutkuje tym, że termin do zaskarżenia orzeczenia nie otwiera się. ${ }^{41}$ Wydaje się, że pogląd ten jest zbyt daleko idący i należy zaakceptować stanowisko E. Wengerka.

\section{Terminowość czynności procesowych a przewlekłość postępowania sądowego}

Problematyka terminów w procesie cywilnym niewątpliwie też wiąże się z przewlekłością postępowania. $\mathrm{Na}$ gruncie polskiej regulacji chodzi o art. 2 ust. 2 ustawy z dnia 17 czerwca 2004 r. o skardze na naruszenie prawa strony do rozpoznania sprawy w postępowaniu przygotowawczym prowadzonym lub nadzorowanym przez prokuratora i postępowaniu sądowym bez nieuzasadnionej zwłoki ${ }^{42}$ w brzmieniu: dla stwierdzenia, czy w sprawie doszło do przewlekłości postępowa-

Patrz także M. Jędrzejewska, K. Weitz, (w:) T. Ereciński (red.), Kodeks postępowania cywilnego. Komentarz, s. 461.

Postanowienie Sądu Najwyższego z dnia 13 lutego 1997 r., I CKN 73/96, Lex nr 50572.

M. Sorysz, Terminy w polskim procesie cywilnym, s. 53.

E. Wengerek, Problem ustności i pisemności postępowania cywilnego, „Nowe Prawo” 1970, nr 10, s. 1410.

B. Bladowski, Wydanie wyroku w procesie cywilnym, „Nowe Prawo” 1983, nr 11-12, s. 41.

B. Bladowski, Zażalenie w postępowaniu cywilnym, Kraków 1998, s. 54.

Dz.U. Nr 179, poz. 1843 ze zm., zwana dalej „skargą na przewlekłość postępowania”. 
nia, należy w szczególności ocenić terminowość i prawidłowość czynności podjętych przez sąd, w celu wydania w sprawie rozstrzygnięcia co do istoty albo czynności podjętych przez prokuratora prowadzącego lub nadzorującego postępowanie przygotowawcze $\mathrm{w}$ celu zakończenia postępowania przygotowawczego lub czynności podjętych przez sąd lub komornika sądowego w celu przeprowadzenia i zakończenia sprawy egzekucyjnej albo innej sprawy dotyczącej wykonania orzeczenia sądowego, uwzględniając charakter sprawy, stopień faktycznej i prawnej jej zawiłości, znaczenie dla strony, która wniosła skargę, rozstrzygniętych w niej zagadnień oraz zachowanie się stron, a w szczególności strony, która zarzuciła przewlekłość postępowania. Widać więc wyraźnie, iż jednym z podanych przykładowo kryteriów do stwierdzenia, czy w danej sprawie doszło do przewlekłości, jest ocena, czy czynności podejmowane przez sąd czy inne podmioty były dokonywane terminowo.

Ze względów porządkowych podać należy, iż przedmiotowym żądaniem skargi na przewlekłość postępowania ustawodawca uczynił stwierdzenie, że w postępowaniu, którego skarga dotyczy, nastapiło naruszenie jej prawa do rozpoznania sprawy bez nieuzasadnionej zwłoki, jeżeli postępowanie w tej sprawie trwa dłużej niż to konieczne dla wyjaśnienia tych okoliczności faktycznych i prawnych, które są istotne dla rozstrzygnięcia sprawy, albo dłużej niż to konieczne do załatwienia sprawy egzekucyjnej lub innej dotyczącej wykonania orzeczenia sądowego (przewlekłość postępowania) - art. 2 ust. 1 Ustawy. Przewlekłość jest pojęciem mówiącym, że jakieś zdarzenie lub stany są nadmiernie rozciagnięte w czasie, rozwleczone, przedłużają się. Jest to pojęcie względne, a zatem zawsze musi być odnoszone do konkretnych realiów i podjętego trybu postępowania. Musi być do niego adekwatne, a zatem jedynie nadmierne odstępstwa od czasu zwyczajowo koniecznego do wykonania określonych prac i procedur mogą być uznawane za tworzące stan nieuzasadnionej zwłoki. ${ }^{43}$

Analizy, co należy rozumieć pod pojęciem terminowości dokonywania czynności, należy dokonywać głównie przez pryzmat orzeczeń sądowych, z uwagi na fakt stosunkowo skromnej literatury w tej materii, a po drugie, iż dopiero praktyka stosowania tej instytucji daje możliwość doprecyzowania ogólnych rozwiązań ustawowych.

Ustalenie zaistnienia przewlekłości postępowania nie jest zależne jedynie od upływu czasu i subiektywnych odczuć skarżącego, a jest wypadkową czynników obiektywnych oraz czasu niezbędnego do podejmowania działań zgodnych z obo-

43 P. Górecki, S. Stachowiak, P. Wiliński, Skarga na przewlekłość postępowania przygotowawczego. Komentarz, wyd. 2, Warszawa 2010, s. 40. Zob. także postanowienie Sądu Apelacyjnego w Krakowie z dnia 22 marca 2007 r., II S 1/07, KZS 2007, nr 3, poz. 42 w brzmieniu: przewlekłość postępowania zachodzi, gdy jest ono długotrwałe, prowadzone rozwlekle i trwa ponad konieczność wyjaśnienia okoliczności faktycznych i prawnych niezbędnych do końcowego rozstrzygnięcia, będących w związku przyczynowym z działaniem lub bezczynnością sądu. 
wiązującymi przepisami przewidującymi prowadzenie określonych procedur. Przewlekłość jest bowiem pojęciem mówiącym, iż jakieś zdarzenia czy stany są nadmiernie rozciagnięte w czasie, rozwleczone i przedłużają się. Jest to, co oczywiste, pojęcie względne, a zatem zawsze musi być odnoszone do konkretnych realiów sprawy i przyjętego trybu postępowania. Jedynie nadmierne odstępstwa od czasu koniecznego do wykonania określonych czynność sądowych, prac i procedur mogą być uznawane za tworzące stan nieuzasadnionej zwłoki, o jakim mowa w ustawie $\mathrm{z}$ dnia 17 czerwca $2004 \mathrm{r}^{44}$

Ocena terminowości i prawidłowości postępowania obejmować powinna m.in. takie okoliczności, jak: przerwy zarządzane między terminami posiedzeń, wadliwa organizacja posiedzeń, powoływanie biegłych przedstawiających opinię dotyczącą tej samej problematyki, terminowość działania biegłych, zasadność prowadzenia uzupełniającego postępowania dowodowego. Przewlekłość może dotyczyć także przekazywania akt sprawy, wyznaczania terminów rozpraw oraz podejmowania rozstrzygnięć, sporządzania i doręczania uzasadnień. ${ }^{45}$

Naruszenie prawa do osądzenia sprawy bez zbędnej zwłoki (przewlekłość postępowania) zachodzi nie tylko w razie indywidualnej sytuacji opieszałości działań sędziego czy jego sekretariatu, ale i wskutek wadliwej organizacji pracy, w tym nieprawidłowego założenia, że sprawy obszerniejsze będą rozpoznawane w postępowaniu odwoławczym po upływie roku od wniesienia, a sprawy mniej obszerne - bez zwłoki, co sprowadza się w praktyce do czterech miesięcy od ich nadesłania. Nie negując potrzeby dłuższego przygotowywania się do podjęcia decyzji w sprawach obszernych, Sąd Apelacyjny wyraża przekonanie, że nie powinno to prowadzić do tak dużej zwłoki. Nie można oczekiwać rozpoznawania sprawy niezwłocznie po jej wniesieniu. Żadne społeczeństwo nie byłoby w stanie utrzymać tak dużej ilości sędziów, jaka byłaby po temu niezbędna. Niezwłoczne rozstrzyganie sprawy nie jest możliwe ani ze względów organizacyjnych (doręczenie stronom zawiadomień o miejscu i terminie rozprawy), ani nie byłoby to rozsądne wobec konieczności zapoznania się sędziów z materiałami sprawy, czasu dla ich rozważenia i podjęcia decyzji, wreszcie - jej uzasadnienia. Chodzi o to jedynie, by czynności te zabierały odpowiednią ilość czasu, to jest odbywały się bez zbędnej zwłoki, która wskazywałaby na bezczynność sądu lub bezproduktywność jego działan. ${ }^{46}$

Opóźnienie w doręczeniu skarżącemu odpisu uzasadnienia wyroku nie może przesądzać o istnieniu przewlekłości postępowania. Ocenie podlega bowiem czas

\footnotetext{
44 Postanowienie Sądu Apelacyjnego w Katowicach z dnia 11 maja 2005 r., II S 26/05, KZS 2005, nr 7-8, poz. 158.

45 P. Górecki, S. Stachowiak, P. Wiliński, Skarga na przewlekłość postępowania przygotowawczego. Komentarz, s. 45.

46 Postanowienie Sądu Apelacyjnego w Krakowie z dnia 1 października 2008 r., II S 6/08, KZS 2008, nr 11, poz. 70.
} 
trwania całości postępowania, a nie terminowość podejmowania przez sąd poszczególnych czynności. Nie wyklucza to możliwości stwierdzenia przewlekłości postępowania z powodu nieterminowości podjęcia przez sąd jednej czynności, ale jest to możliwe tylko wtedy, gdy opóźnienie w wykonaniu tej czynności jest tak znaczne, że powoduje przewlekłość całego postępowania. ${ }^{47}$

Co do zasady, postępowanie sądowe jest przewlekłe, jeżeli toczy się ponad 12 miesięcy. $^{48}$

\section{Uwagi końcowe}

Z powyższego, ogólnego opracowania można wyciągnąc jednoznaczny wniosek, że tematyka poświęcona terminom procesowym jest trudna oraz złożona, a jednocześnie pełni niezwykle doniosłą rolę, stojąc na straży jednego z aspektów prawidłowości dokonywania czynności procesowych stron, sądu i innych podmiotów w postępowaniu cywilnym. Ma to umożliwiać rozpoznawanie spraw sprawnie, zapobiegając zbędnej przewlekłości postępowania (co w pewnym okresie stanowiło gros podstawy żądania skargi skierowanej do Europejskiego Trybunału Praw Człowieka $^{49}$ ), a w 2004 r. zostało usankcjonowane regulacją krajową.

Postanowienie Sądu Najwyższego z dnia 2 lipca 2009 r., III SPP 14/09, Lex nr 551875.

Postanowienie Naczelnego Sądu Administracyjnego z dnia 24 lipca 2008 r., II OPP 20/08, Lex nr 493700.

W 2006 r. Europejski Trybunał Praw Człowieka w Strasburgu wydał przeciwko Polsce 114 wyroków, przy czym tylko w 8 przypadkach uznał, że nie doszło do naruszeń prawa. W około $90 \%$ tych spraw wyroki dotyczyły przewlekłości postępowań sądowych oraz nadmiernej długości tymczasowego aresztowania. W 2008 r. Trybunał na 141 orzeczeń w sprawach polskich stwierdził w 63 przypadkach naruszenie prawa do rozpoznania sprawy; łącznie zaś w latach 1998-2008 na 630 orzeczeń w sprawach polskich 308 z nich dotyczyło kwestii długości postępowania - zob. P. Górecki, S. Stachowiak, P. Wiliński, Skarga na przewlekłość postępowania przygotowawczego. Komentarz, s. 23-24. 


\title{
TERMS IN CIVIL PROCEDURE - SELECTED ISSUSES ABSTRACT
}

\author{
SUMMARY
}

In this article I tried to focus on some aspects of terms in polish civil procedure. Each procedure has it's own regulations which are established to protect speed and effectiveness of the actions made by parties and court. Term itself doesn't matter but connected with the action especially what happens if we overrun a deadline - this is interesting. Of course it is impossible to describe all problems connected with time, terms in civil procedure. Because of that I decided to show only some aspects of this: types of terms (statutory time limit; term fixed by the court; instruction term), similarities and differences between them. The last part describes a new regulation in polish legal system: complaint for lengthiness of proceedings. One of the criteria which courts has to take under consideration is that all the actions have been made in a proper period of time - in this field I focused on especially on verdicts of The Supreme Court. 